University of Nebraska - Lincoln

DigitalCommons@University of Nebraska - Lincoln

1986

Diatom stratigraphy of the lower Pliocene part of the Sisquoc Formation, Harris Grade section, California

John A. Barron

USGS

Jack G. Baldau

Ocean Drilling Program, Texas A\&M University, College Station, Texas 77843-3469

Follow this and additional works at: https://digitalcommons.unl.edu/usgsstaffpub

Part of the Earth Sciences Commons

Barron, John A. and Baldau, Jack G., "Diatom stratigraphy of the lower Pliocene part of the Sisquoc Formation, Harris Grade section, California" (1986). USGS Staff -- Published Research. 268.

https://digitalcommons.unl.edu/usgsstaffpub/268

This Article is brought to you for free and open access by the US Geological Survey at DigitalCommons@University of Nebraska - Lincoln. It has been accepted for inclusion in USGS Staff -- Published Research by an authorized administrator of DigitalCommons@University of Nebraska - Lincoln. 


\title{
Diatom stratigraphy of the lower Pliocene part of the Sisquoc Formation, Harris Grade section, California
}

\author{
John A. Barron ${ }^{1}$ and Jack G. Baldauf ${ }^{2}$ \\ ${ }^{1}$ U.S. Geological Survey, Menlo Park, California 94025 \\ ${ }^{2}$ Ocean Drilling Program, Texas A\&M University, College Station, Texas 77843-3469
}

\begin{abstract}
Lower Pliocene diatoms were studied from the Sisquoc Formation and lowermost Foxen Mudstone, exposed along Harris Grade north of Lompoc, California, to refine the diatom biostratigraphy of post-Monterey Formation sediments in California. Sixty-seven diatom taxa were identified in the 25 samples examined from the $790-\mathrm{m}$ thick (2950-ft) section. The diatoms are assignable to the uppermost Nitzschia reinholdii Zone and Thalassiosira oestrupii Zone of Barron (1981), and five tentative subzones for local correlation are proposed. Regional correlations and taxon occurrence are discussed, and the base of the Nitzschia reinholdii Zone is redefined as at the last occurrence of Thalassionema schraderi.
\end{abstract}

\section{INTRODUCTION}

Middle Miocene to lower Pliocene strata of coastal California are well known for their extensive deposits of diatomaceous rocks (Ingle 1981). Typically, these deposits contain hemipelagic diatomaceous shales of the Monterey Formation (upper lower Miocene to upper Miocene) overlain by more massive, detritus-rich diatomaceous mudstones of the Capistrano Formation, the Malaga Mudstone Member of the Monterey Formation, the Sisquoc Formation, or the Purisima Formation (uppermost Miocene to lower Pliocene) (Ingle 1981; Barron 1986).

Studies by Barron (1975a, 1975b, 1976a, 1976b, 1976c, 1981), Rowell (1981), Baldauf and Barron (1982), and Barron and Keller (1983) have established a workable diatom biostratigraphy for the Monterey Formation. In contrast, few detailed biostratigraphic studies exist for the overlying diatomaceous units, especially the Sisquoc Formation.

Classical exposures of the Monterey and Sisquoc Formations are located in the Johns-Manville Quarry south of Lompoc, California (text-fig. 1). Although Barron (1975a, 1975b), following Dibblee (1950), assigned the majority of the quarry section to the Sisquoc Formation, this sequence properly belongs to the Monterey Formation (Woodring and Bramlette 1950; Wornardt 1967; Barron 1976c; Isaacs 1981). Only the three uppermost samples (ARL-2, -4 , and -8) studied by Barron (1975a, 1975b) are actually assignable to the Sisquoc Formation.

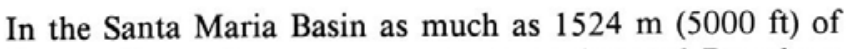
Sisquoc Formation are exposed (Woodring and Bramlette 1950). Woodring and Bramlette (1950) recognized both a basinal facies and a marginal facies in the Sisquoc Formation. The fine-grained basinal facies consists mostly of diatomaceous mudstone but includes some porcelaneous mudstone and claystone. This facies is exposed throughout the central Santa Maria Basin and along the Santa Barbara coast (Woodring and Bramlette 1950; Dibblee 1966). The marginal facies is predominantly composed of sandstone, the Tinaquaic Sandstone Member, and it is exposed only in the northeast portion of the Santa Maria Basin (Woodring and Bramlette 1950).

Geologic studies of the Sisquoc Formation in the Santa Maria
Basin have included those of Porter (1932), Woodring et al. (1943), Woodring and Bramlette (1950), Dibblee (1950), and Wornardt (1963). Each of these studies made use of the Harris Grade section which is exposed along former California State Highway 1 as it crosses the Purisima Hills north of Lompoc (text-fig. 1). At this locality, the lower portion of the Sisquoc is truncated by a fault. The section's base, therefore, is taken as the axis of the Purisima Anticline of Woodring and Bramlette (1950). The section extends from this anticlinal axis northward for $3 \mathrm{~km}$ across the crest of the Purisima Hills. Woodring and Bramlette (1950) measured $899 \mathrm{~m}$ (2950 $\mathrm{ft})$ of Sisquoc Formation overlain by $244 \mathrm{~m}(800 \mathrm{ft})$ of the lower Foxen Mudstone in this section. Wornardt (1963) also recorded $244 \mathrm{~m}(800 \mathrm{ft})$ of Foxen Mudstone in this section, but he reported the thickness of the Sisquoc Formation as $1067 \mathrm{~m}(3500 \mathrm{ft})($ table 1$)$.

Diatoms from the Harris Grade section are discussed by Woodring et al. (1943), Simonsen and Kanaya (1961), and Wornardt $(1963,1967)$. Simonsen and Kanaya's (1961) study was restricted to the genus Denticulopsis, but Woodring et al. (1943) and Wornardt (1963, 1967) followed the practice of earlier diatom biostratigraphers by concentrating on diatoms visible at $\times 250$, and failing to document the stratigraphically useful smaller forms $(5-30 \mu \mathrm{m})$, such as Thalassiosira, which dominate Sisquoc Formation assemblages (Barron 1975a, 1975b). Recent studies have stressed the importance of smaller forms in late Neogene biostratigraphy of the middle latitude northeastern Pacific (Burckle and Opdyke 1977, 1985; Barron 1981; Dumont 1984; Whiting and Schrader 1985). These studies indicate the need to document such forms in the Harris Grade section and other exposures of the Sisquoc Formation in order to improve the stratigraphic correlation and resolution of onshore sections.

Although the base of the Sisquoc Formation is not exposed in the Harris Grade section, the Sweeney Road section east of Lompoc contains about $700 \mathrm{~m}(2300 \mathrm{ft})$ of lower Sisquoc Formation where it unconformably overlies the Monterey Formation (Dibblee 1950; Barron 1974). A reconnaissance study of the diatoms of the Sweeney Road section was completed by Barron (1974), and a more thorough study is presently under way by Dumont (1984) as part of a Master's Thesis at the University of California, Berkeley. Earlier work 


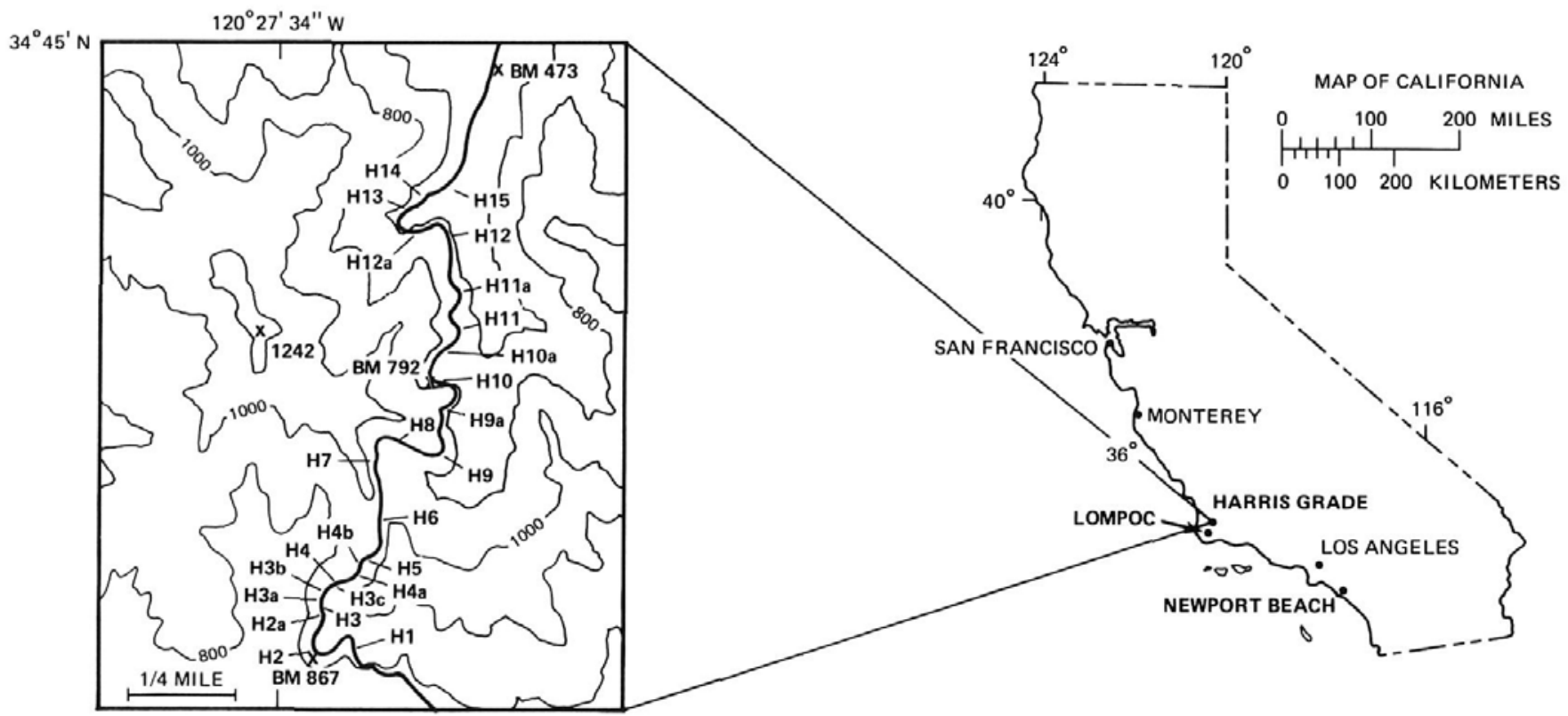

TEXT-FIGURE 1

Location of Harris Grade section in Santa Barbara County, California, and location of samples studied along Harris Grade. H-1, lowest sample

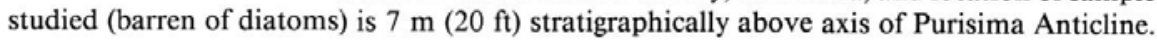

(John Ruth, oral communication 1973) suggested that the upper part of the Sweeney Road section correlates with the lower part of the Harris Grade section, a conclusion which is supported by our reconnaissance studies. The Harris Grade study when combined with Dumont's (1984) ongoing study of the Sweeney Road section, helps to refine the latest Miocene to early Pliocene diatom biostratigraphy of California.

\section{MATERIALS AND METHODS}

A total of 25 samples were collected from the Harris Grade section during the 1983 and 1984 field seasons (text-fig. 1). The stratigraphic intervals of these samples were estimated by their measured bedding attitudes and horizontal distance along the highway, as well as by comparison with the sample intervals of Simonsen and Kanaya (1961) and Woodring and Bramlette (1950).

Because the Sisquoc Formation contains little or no calcareous material, the samples were not processed in acid. Rather, strewn slides were prepared using the following technique. A sample measuring approximately $1 \mathrm{cub} \mathrm{cm}$ was placed into a 4-dram vial. The vial was filled with distilled water and the sample was disaggregated mechanically with a stirring rod and by agitation of the vial. Strewn slides were prepared following the techniques of Schrader and Gersonde (1978).

At least two slides (cover glass size $30 \times 22 \mathrm{~mm}$ ) were examined in their entirety under the light microscope at a magnification of $\times 500$. Species identifications were confirmed at $\times 1250$. The relative abundance of each species was estimated in the following manner: abundant, two or more specimens per field of view $(\times 500)$; common, one specimen in two fields of view; few, one specimen in each horizontal traverse (length $30 \mathrm{~mm}$ ); and rare, if a specimen was encountered less frequently.
TABLE 1

Comparison of lithologic units of Woodring and Bramlette (1950) and Wornardt (1963).

\begin{tabular}{|c|c|c|}
\hline & $\begin{array}{l}\text { Woodring and Bramlette } \\
\qquad(1950)\end{array}$ & Wornardt (1963) \\
\hline $\begin{array}{l}\text { Lower } \\
\text { Foxen } \\
\text { Mudstone }\end{array}$ & $\begin{array}{l}244 \mathrm{~m}(800 \mathrm{ft}) \text { mud- } \\
\text { stone, clayey silt- } \\
\text { stone and thin beds } \\
\text { of silty sandstone. }\end{array}$ & $\begin{array}{c}244 \mathrm{~m}(800 \mathrm{ft}) \text { clayey } \\
\text { siltstone, thin beds } \\
\text { of silty sandstone, } \\
\text { and a few layers of } \\
\text { diatomaceous shale. }\end{array}$ \\
\hline $\begin{array}{l}\text { Upper } \\
\text { Sisquoc } \\
\text { Formation }\end{array}$ & $\begin{array}{l}236 \mathrm{~m}(775 \mathrm{ft}) \text { light } \\
\text { colored diatoma- } \\
\text { ceous mudstone. } \\
\text { Forms bare outcrops, } \\
\text { between which are } \\
\text { stands of brush. }\end{array}$ & $\begin{array}{l}274 \mathrm{~m}(900 \mathrm{ft}) \text { light } \\
\text { colored diatom- } \\
\text { mudstone, shale, } \\
\text { and diatomite. }\end{array}$ \\
\hline $\begin{array}{l}\text { Sisquoc } \\
\text { Formation }\end{array}$ & $\begin{array}{l}76 \mathrm{~m}(250 \mathrm{ft}) \text { clayey } \\
\text { diatomaceous mud- } \\
\text { stone containing few } \\
\text { diatoms. Supports } \\
\text { growth of grass. }\end{array}$ & $\begin{array}{l}152 \mathrm{~m}(500 \mathrm{ft}) \text { clayey } \\
\text { diatomite, shale. }\end{array}$ \\
\hline $\begin{array}{l}\text { Sisquoc } \\
\text { Formation }\end{array}$ & $\begin{array}{l}434 \mathrm{~m}(1425 \mathrm{ft}) \text { light } \\
\text { colored diatoma- } \\
\text { ceous mudstone. } \\
\text { Forms bare outcrops, } \\
\text { between which are } \\
\text { stands of brush. Di- } \\
\text { atomite may be lam- } \\
\text { inated. }\end{array}$ & $\begin{array}{l}457 \mathrm{~m} \text { (1500 ft) light } \\
\text { colored diatoma- } \\
\text { ceous mudstone. }\end{array}$ \\
\hline $\begin{array}{l}\text { Lower } \\
\text { Sisquoc } \\
\text { Formation }\end{array}$ & $\begin{array}{l}91 \mathrm{~m}(300 \mathrm{ft}) \text { porcela- } \\
\text { neous shale with } \\
\text { thin, cherty layers. } \\
\text { Thickness uncertain } \\
\text { due to folding and } \\
\text { faulting at crest of } \\
\text { anticline. }\end{array}$ & $\begin{array}{l}182 \mathrm{~m}(600 \mathrm{ft}) \text { porce- } \\
\text { laneous shale in- } \\
\text { terbedded with dia- } \\
\text { tomaceous } \\
\text { mudstone. }\end{array}$ \\
\hline
\end{tabular}


Sample preservation is judged by the abundance of finely silicified forms such as Actinocyclus ehrenbergii Ralfs, Cocconeis spp., and Nitzschia spp. compared with the abundance of more robust forms such as Coscinodiscus marginatus Ehrenberg, C. oculus-iridis Ehrenberg, Lithodesmium cornigerum Brun, Rhizosolenia barboi Brun, and Thalassionema nitzschioides Grunow.

\section{DIATOM BIOSTRATIGRAPHY}

\section{Diatom zonation}

Text-figure 2 correlates the diatom zones of Koizumi (1973) and Barron (1980) for the northwest Pacific with the diatom zones of Barron (1981) for the northeast Pacific. The base of the Denticulopsis kamtschatica Zone of Koizumi (1973) is defined at the first occurrence of Denticulopsis kamtschatica (Zabelina) Simonsen while its top is defined by the first occurrence of $D$. seminae var. fossilis (Schrader) Simonsen. Barron (1980) proposed three subzones for the D. kamtschatica Zone based on the last occurrences of Rouxia californica M. Peragallo and Cosmiodiscus insignis Jousé.

In the northwest Pacific and Bering Sea, D. kamtschatica first occurs in the uppermost Miocene (ca 6.5 Ma); however, its first occurrence in California sections was delayed until the Pliocene (ca 5.2 Ma) (Barron, 1976a; Harper, 1977; Burckle and Opdyke, 1985). Consequently, it is inappropriate to use the D. kamtschatica Zone in California, and Barron (1976a) proposed using refined versions of Schrader's (1973) North Pacific Diatom (NPD) Zones X and IX for this latest Miocene to early Pliocene interval in California. Later, Barron (1981) renamed NPD Zones X and IX the Nitzschia reinholdii and Thalassiosira oestrupii Zones, respectively.

The Nitzschia reinholdii Zone is defined by Barron (1981) as the interval from the first occurrence of Nitzschia reinholdii Kanaya ex Barron et Baldauf to the first occurrence of Thalassiosira oestrupii (Ostenfeld) Proshkina-Lavrenko. Nitzschia reinholdii is sporadic and sparse throughout the $N$. reinholdii Zone, and is a poor marker for the base of the $N$. reinholdii Zone (Barron 1981; Barron and Keller 1983). The last occurrence of Thalassionema schraderi Akiba, on the other hand, is a useful stratigraphic marker throughout the middle-latitude North Pacific (Akiba 1982; Maruyama 1984; Barron 1985). The last occurrence of Thalassionema schraderi correlates with the upper part of polarity Chron 7 (ca 6.7 Ma) according to Barron (1980) and Koizumi (1985), and is slightly below the first occurrence of $N$. reinholdii (ca 6.5 Ma). Consequently, the last occurrence of $T$. schraderi appears to be a better marker for the base of the Nitzschia reinholdii Zone than the first occurrence of $N$. reinholdii. The base of the Nitzschia reinholdii Zone of Barron (1981), there-

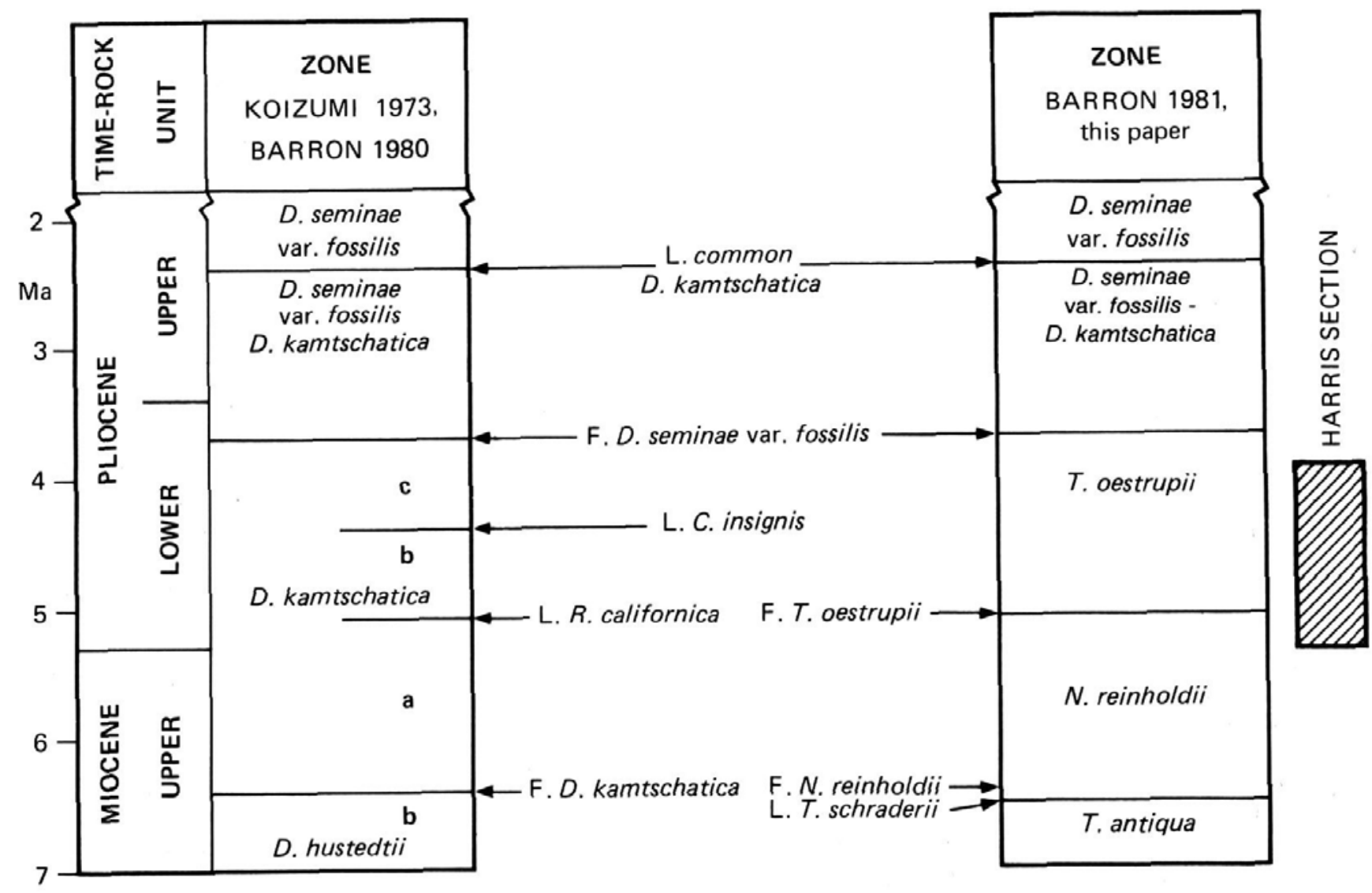

TEXT-FIGURE 2

Comparison of diatom zonation of Koizumi (1973) and Barron (1980) for northwestern Pacific with diatom zonation of Barron (1981) for middle-latitude northeastern Pacific. $\mathrm{F}=$ first occurrence datum; $\mathrm{L}=$ last occurrence datum. 
fore, is herein redefined at the last occurrence of $T$. schraderi. It should be pointed out that Thalassionema hirosakiensis (Kanaya) Schrader as identified by Barron (1981) and Barron and Keller (1983) in California sections is assigned to $T$. schraderi by Akiba (1982). The first occurrence of Thalassiosira oestrupii, Barron's (1981) marker for the top of the $N$. reinholdii Zone, is retained.

NPD Zone $\mathrm{X}$ is divisible into two subzones by the last consistent occurrence of Rouxia californica (Barron 1976a), so the Nitzschia reinholdii Zone can be similarly subdivided. The last consistent occurrence of $R$. californica is correlated with the uppermost part of polarity Chron 6 (ca $6 \mathrm{Ma}$ ), based on the paleomagnetic studies of Madrid et al. (in press) on the Purisima Formation at Santa Cruz in northern California, a result consistent with the extrapolations of Barron (1981) and Barron and Keller (1983). The last occurrence of $R$. californica recorded by Barron (1980) off Japan, however, approximates the Miocene/Pliocene boundary (ca 5.2 Ma), attesting to the diachroneity of this datum level reported by Harper (1977).

The Thalassiosira oestrupii Zone is the interval between the first occurrence of Thalassiosira oestrupii and the first occurrence of Denticulopsis seminae var. fossilis, and it is therefore equivalent to Subzones b and c of the D. kamtschatica Zone (Barron 1981).

\section{Harris Grade biostratigraphy}

The occurrences of diatom taxa encountered in the 23 samples from the Harris Grade section are shown on table 2. Samples H-1 (39 m) and H-2 (58 m) are barren of diatoms, which is to be expected as they are from the lower 100-mthick porcelaneous shale unit of Woodring and Bramlette (1950). Sample H-15 (905 m) is from the basal Foxen Mudstone, approximately $6 \mathrm{~m}$ above the contact with the Sisquoc Formation.

The first occurrence of Thalassiosira oestrupii in Sample H-3C $(160 \mathrm{~m})$ marks the base of the $T$. oestrupii Zone. Because Denticulopsis seminae var. fossilis does not occur in the overlying samples, the entire upper portion of the Harris Grade section is assigned to the $T$. oestrupii Zone. The presence of Nitzschia reinholdii and the absence of both Rouxia californica and Thalassionema schraderi in Samples H-2A (100 m) through $\mathrm{H}-3 \mathrm{~B}(151 \mathrm{~m})$, places the lower diatom-bearing interval of the Harris Grade section in Subzone b of the Nitzschia reinholdii Zone.

Further biostratigraphic subdivision of the Harris Grade section is suggested by the range of selected species. At least five subzones can be recognized. Samples $\mathrm{H}-2 \mathrm{~A}$ though $\mathrm{H}-3 \mathrm{~B}$ lack Thalassiosira oestrupii but contain $T$. praeoestrupii Dumont, Baldauf and Barron (1986) and Lithodesmium cornigerum, and are assignable to Subzone 1 within the uppermost part of the Nitzschia reinholdii Zone. Samples H-3C through H-6 contain the stratigraphic overlap of $T$. oestrupii and $T$. nativa Sheshukova-Poretzkaya and constitute a lower subzone (= Subzone 2 ) of the $T$. oestrupii Zone. In Samples $\mathrm{H}-9$ through $\mathrm{H}-8, T$. praeoestrupii and $T$. hyalinopsis Barron range above the last occurrence of $T$. nativa (= Subzone 3 ). Samples H-9A through H-11 are tentatively assigned to Sub- zone 4 wherein Lithodesmium cornigerum and L. minusculum Grunow range stratigraphically above the last occurrences of $T$. praeoestrupii and $T$. hyalinopsis. Finally, Samples $\mathrm{H}-11 \mathrm{~A}$ through $\mathrm{H}-15$ are distinguished by the range of Denticulopsis kamtschatica and $T$. oestrupii above the range of Lithodesmium species (= Subzone 5).

Further studies are required to determine whether these various subzones are useful throughout the Santa Maria Basin of California. Subzone 1 has been recognized in the lower Capistrano Formation and in the Purisima Formation (Barron and Keller 1983 and Barron unpublished data).

\section{Age of the Harris Grade section}

Thalassiosira oestrupii first occurs in Sample H-3C and ranges to the top of the Harris Grade section. The first occurrence of Thalassiosira oestrupii falls in the lower reversed event of the Gilbert Reversed Polarity Chron in the Equatorial Pacific, slightly above the Miocene/Pliocene boundary (Burckle 1978; Barron et al. 1985). The isochroneity of this datum level in the middle latitude North Pacific has been demonstrated by Burckle (1978) and Barron (1980, 1981) implying that Sample H-3C lies slightly above the Miocene/Pliocene boundary. Koizumi and Tanimura (1985) reported that the first occurrence of $T$. oestrupii coincides with the top of polarity Chron 5 at northwest Pacific DSDP Site 578; however, these two events fall at the break between Cores 578-12 and 578-13, so the correlation is implied.

Underlying Samples H-2a through H-3B at Harris Grade contain Thalassiosira praeoestrupii, a diatom which first occurs at the top of Chron 5 in California according to the paleomagnetic studies of Madrid et al. (in press) and Dumont et al. (1986) at Santa Cruz. Because Berggren et al. (1985) placed the Miocene/Pliocene boundary at the top of polarity Chron 5, Sample H-2A, the lowermost Harris Grade Sample containing diatoms, would be earliest Pliocene in age.

Lithodesmium cornigerum also occurs in Sample H-2A. Early diatom workers (Woodring et al. 1943; Hanna 1930; Wornardt 1963,1967$)$ considered $L$. cornigerum to be a marker for the Pliocene, but this has been poorly substantiated by correlations with the international geologic time scale. Schrader (1973) reported L. cornigerum in his North Pacific Diatom Zone IX, which is equivalent to the Thalassiosira oestrupii Zone or early Pliocene. Barron (1976a) noted the first occurrence of $L$. cornigerum in his sample $\mathrm{N}-14$ a from the lower Capistrano Formation at Upper Newport Bay in southern California, about $10 \mathrm{~m}$ stratigraphically above sample N-14 where T. oestrupii sensu Barron (1976a) first occurs. Thalassiosira oestrupii sensu Barron (1976a) is actually $T$. praeoestrupii (see Taxonomic Notes and Barron and Keller 1983), so near coincidence of the first occurrences of $T$. praeoestrupii and L. cornigerum in the lowermost Capistrano Formation at Upper Newport Bay is suggested. The near coincidence of the first occurrences of these two species has also been observed in the Sweeney Road section of the Sisquoc Formation by M. Dumont (oral communication 1985). Arends (oral communication 1985), on the other hand, has observed $L$. cornigerum ranging into the latest Miocene part of the $N$. reinholdii Zone in southern California. 
TABLE 2

Stratigraphic occurrence and abundance of diatom species and varieties observed from Harris Grade samples. Stratigraphic interval in meters above base of section (= axis of the Purisima Anticline). $\mathrm{R}=$ rare, $\mathrm{F}=$ few, $\mathrm{C}=$ common, $\mathrm{A}=$ abundant, $\mathrm{r}=$ reworked, $\mathrm{P}=$ poor, $\mathrm{M}=$ moderate, $\mathrm{G}=$ good.

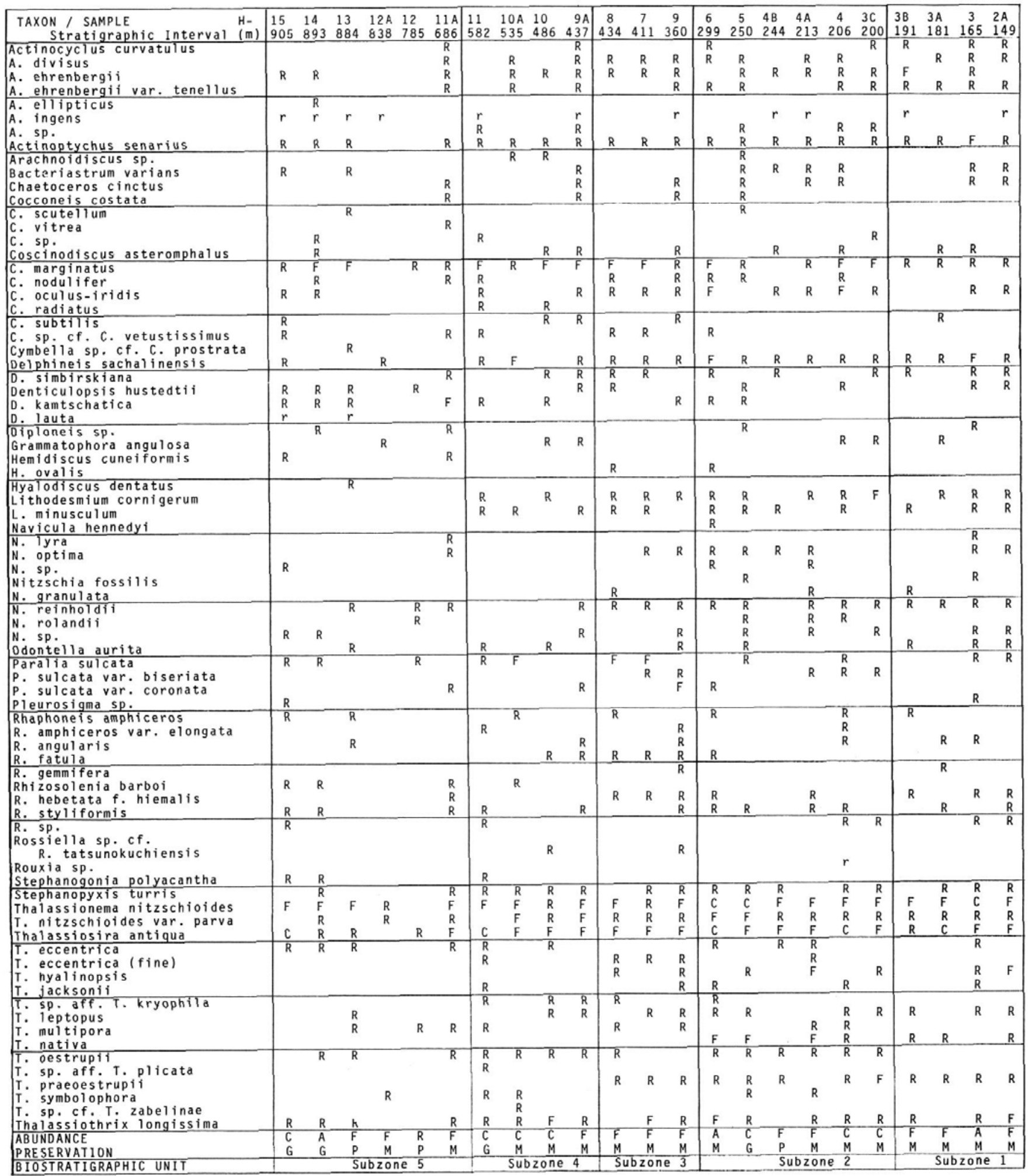


The upper age constraint on the Harris Grade section samples is provided by the absence of Denticulopsis seminae var. fossilis, a diatom which first occurs in the uppermost part of the Gilbert Reversed Polarity Chron (ca 3.7 Ma) in the middle-latitude North Pacific (Koizumi and Tanimura, 1985). Because D. seminae var. fossilis is recorded in DSDP Sites 467 and 469 off southern California by Barron (1981), it seems unlikely that it was ecologically excluded from the Santa Maria Basin area. Accordingly, the entire Harris Grade section appears to be early Pliocene in age.

The early Pliocene age assignment of the Harris Grade section is supported by the occurrence of Delmontian Stage foraminifers in the upper part of the Sisquoc exposed in the section (Woodring and Bramlette 1950). According to Warren (in Kleinpell 1980), the Delmontian Benthonic Foraminiferal Stage does not range younger than about $4.0 \mathrm{Ma}$ or early Pliocene.

Stanley and Surdham (1984) equate an unconformity separating the Sisquoc Formation with the overlying Foxen Mudstone to a 4.2 Ma drop in global sea-level shown by Vail and Hardenbol (1979), based on correlations of mollusks, benthic foraminifers and gross lithology. Similarly, Barron (1981, 1986) observed that diatom-rich sediments, which are prevalent in the middle Miocene through earliest Pliocene of California, do not range above 4.0 to $4.5 \mathrm{Ma}$. The absence of diatoms described from both the equatorial Pacific (Nitzschia jouseae Burckle and $N$. cylindrica Burckle) and the northwest Pacific (Cosmiodiscus insignis and Coscinodiscus temperei Brun) with datum levels between 4.5 and 4.0 Ma in the Harris Grade section prevents confirmation of the suggestions by Stanley and Surdham (1984) and Barron (1986) that the top of the Sisquoc Formation is older than 4.0 Ma. Although it is possible that the entire Harris Grade section predates the first occurrence of $N$. jouseae $(4.5 \mathrm{Ma})$, it is more likely that transitional paleotemperatures and the inshore site of deposition of the Harris Grade section combined to actively exclude $N$. jouseae from the area. This conclusion is supported by the absence of $N$. jouseae in the lower Pliocene parts of DSDP Sites 467 and 469 off southern California.

Most of the lower Pliocene at DSDP Site 173 is absent due to a hiatus (Keller 1979; Barron and Keller 1983), so that Site 173 cannot be used as a lower Pliocene reference section for comparison with the Harris Grade section. It is hoped that study of the lower Pliocene diatomaceous sections of DSDP Sites 32 and 34 now under way by Baldauf and Dumont (in prep.) will allow refined age resolution of the lower Pliocene of California.

\section{Comparison with earlier studies}

Earlier studies by Woodring et al. (1943) and Wornardt (1963, 1967) emphasized larger diatom taxa visible at lower power (about $\times 250$ ) which were concentrated in part by sieving. The different techniques employed by us and our emphasis on planktonic species of Thalassiosira, Nitzschia, and Denticulopsis make direct comparison of our results with those of Woodring et al. (1943) and Wornardt $(1963,1967)$ difficult. Modern diatom biostratigraphic studies emphasize smaller taxa and are completed at $\times 500$ or greater. Generally, at least one unsieved slide containing 500 or more spec- imens is examined in its entirety before a sieved slide is examined.

Woodring et al. (1943) identified 220 species and varieties of diatoms in samples collected from the lower portion of the Harris Grade section. Their samples were not arranged stratigraphically. They characterized the basinal facies of the Sisquoc Formation by the following diatom species: Melosira clavigera Grunow, $M$. recedens Schmidt, Stephanopyxis turris var. cylindrus Grunow, Endictya robusta (Greville) Hanna \& Grant, Coscinodiscus aeginensis Schmidt, C. intersectus Brun, C. obscurus Schmidt, C. stellaris Roper, C. vetustissimus Pantocsek, Actinocyclus ehrenbergii, Actinoptychus marmoreus Brun, A. perisetosus Brun, Lithodesmium cornigerum, Xanthiopyxis ovalis Lohman, and Thalassionema nitzschioides. They also noted that pelagic species compose about two-fifths of the observed taxa.

Wornardt (1963) tabulated 120 diatom species and varieties from 17 samples collected from Harris Grade and illustrated them in a later paper (Wornardt 1967). He distinguished a lower flora characterized by Actinocyclus ehrenbergii, Bacteriastrum varians Lauder, Coscinodiscus eccentricus [= Thalassiosira antique (Grunow) Cleve Euler], C. marginatus, $C$. lineatus [ $=T$. leptopus (Grunow) Hasle et Fryxell], $C$. radiatus Ehrenberg, Lithodesmium cornigerum, Nitzschia pliocena $[=N$. reinholdii], and Rhaphoneis ischaboenis [= Delphineis sachalinensis (Sheshukova-Poretzkaya) Barron et Baldauf]. This was followed by a middle flora wherein Coscinodiscus asteromphalus Ehrenberg, C. obscurus, Biddulphia aurita (Lyngbye) Brébisson [= Odontella aurita (Lyngbye) Agardh], and Hemidiscus simplicissimus Hanna et Grant make their first appearance. Lithodesmium cornigerum and $R$. ischaboensis become rare near the upper limit of the middle flora. Wornardt's (1967) upper flora contains the first occurrences of Arachnoidiscus ehrenbergii, Asteromphalus arachne (Brébisson) Ralfs, Coscinodiscus lineatus var. convexus (Ehrenberg) Wornardt (= Thalassiosira leptopus) and Coscinodiscus robustus var. herculus J. Brun, while including the last appearances of $L$. cornigerum and $R$. ischaboensis.

The diatom occurrences in table 2 do not reveal Wornardt's (1967) three Harris Grade floras. Although some of Wornardt's (1967) taxa were not recognized in our study (note that Hemidiscus simplicissimus was not separated from $H$. cuneiformis Wallich), those that can be compared do not show the restriction in the Harris Grade section that Wornardt (1967) claimed. An exception is Lithodesmium cornigerum, which is also absent from the upper part of the section in our study.

Wornardt (1967) compared the Harris Grade diatom assemblage to the type Delmontian diatom assemblage, which he considered to be latest Miocene in age. It is now known that the type Delmontian section near Monterey is latest middle Miocene to earliest late Miocene in age (Barron 1976b). Based on this comparison with the type Delmontian section, as well as molluscan correlations and superpositional relationships, Wornardt (1967) assigned the Harris Grade section to the lower Pliocene. This age assignment is supported by our refined diatom correlations. 
Simonsen and Kanaya (1961) studied the Denticulopsis species in 10 samples from the Harris Grade section; seven from the Sisquoc Formation and three from the overlying Foxen Mudstone. They noted the first occurrence of Denticulopsis kamtschatica in their sample 17 , approximately $686 \mathrm{~m} \mathrm{(2250 \textrm {ft } )}$ above the section base. Simonsen and Kanaya (1961) placed the Miocene/Pliocene boundary immediately below their sample 17 based on provincial benthonic foraminiferal stratigraphy. That sample approximates our Sample H-11A, where $D$. kamtschatica is relatively common, but we record D. kamtschatica down to our Sample H-5, over 450 m (1476 $\mathrm{ft})$ lower in the section.

\section{SISQUOC FORMATION FLORA}

Barron (1975b) defined a Thalassiosira hyalinopsis Assemblage Zone in samples from the basal Sisquoc Formation (see Barron 1976b) in the Johns-Manville Quarry, and he noted its presence (Barron 1975b) in the Sisquoc Formation along Sweeney Road east of Lompoc. Barron (1975b) characterized the assemblage as containing greater than $5 \%$ Thalassionema nitzschioides, Thalassiosira antiqua, $T$. lineata Jousé $(=T$. leptopus), and $T$. hyalinopsis, but he also noted the presence of Bacteriastrum delicatulum Cleve, B. varians, Thalassiosira kryophila (Grunow) Jorgensen, T. oestrupii, and Coscinodiscus subtilis Ehrenberg, taxa which are not found in the Monterey Formation. This assemblage was not observed in the Harris Grade section, because the basal portion of the Sisquoc Formation is missing.

Additional taxa that are absent from the Monterey Formation but present in the Sisquoc Formation and other postMonterey rocks in California include: Denticulopsis kamtschatica, Hemidiscus ovalis Lohman, Nitzschia granulata Grunow, Rhaphoneis fatula Lohman, Rossiella sp. cf. $R$. tatsunokuchiensis (Koizumi) Gersonde, Thalassiosira jacksonii Koizuma et Barron, T. multipora Whiting et Schrader, $T$. praeoestrupii, T. symbolophora Schrader, and T. sp. cf. T. zabelinae Jousé.

\section{CONCLUSION}

The diatoms from 23 samples of the Sisquoc Formation and the basal Foxen Mudstone along Harris Grade north of Lompoc, California, are assignable to the uppermost Nitzschia reinholdii Zone and Thalassiosira oestrupii Zones of Barron (1981) and are early Pliocene in age. The Harris Grade diatom assemblage can also be locally subdivided into five subzones: Subzone $1=$ the occurrence of $T$. praeoestrupii and Lithodesmium cornigerum prior to the first occurrence of $T$. oestrupii; Subzone $2=$ the stratigraphic overlap of $T$. oestrupii and $T$. nativa; Subzone $3=$ the range of $T$. praeoestrupii and T. hyalinopsis above the last occurrence of $T$. nativa; Subzone $4=$ the range of Lithodesmium minusculum Grunow and $L$. cornigerum above the last occurrences of $T$. praeoestrupii and $T$. hyalinopsis; and Subzone $5=$ the range of $T$. oestrupii and Denticulopsis kamtschatica above the last occurrence of Lithodesmium species.

\section{FLORA LIST}

Listed are citations for the diatom taxa shown on table 2. These taxa are illustrated and discussed in Lohman (1938),
Wornardt (1967), Barron (1975a, 1976a, 1981), and Whiting and Schrader (1985). Citation to figures in this paper appear in parenthesis. A formal taxonomic section does not appear here. Comments are added for taxa that occur in the Sisquoc Formation but are absent from the Monterey Formation.

Actinocyclus curvatulus Janisch in Schmidt et al.

Actinocyclus divisus (Grunow) Hustedt

Actinocyclus ehrenbergii Ralfs in Pritchard

Actinocyclus ehrenbergii var. tenellus (Brébisson) Hustedt

Actinocyclus ellipticus Grunow

Actinocyclus ingens Rattray

Actinoptychus senarius (Ehrenberg) Ehrenberg. Synonym: A. undulatus (Bailey) Ralfs.

Bacteriastrum varians Lauder, in Schmidt et al. 1874-1959, pl. 328, figs. 1-5; Barron 1975a, pl. 4, fig. 8. Remarks: Although specimens of Bacteriastrum are present in the uppermost Monterey Formation at Upper Newport Bay (Barron unpublished data), they are usually restricted to post-Monterey rocks in California.

Chaetoceros cinctus Gran
Coconeis costata Gregory
Cocconeis scutellum Ehrenberg
Cocconeis vitrea Brun
Coscinodiscus asteromphalus Ehrenberg
Coscinodiscus marginatus Ehrenberg
Coscinodiscus nodulifer Schmidt
Coscinodiscus oculus-iridis Ehrenberg
Coscinodiscus radiatus Ehrenberg

Coscinodiscus subtilis Ehrenberg; Lohman 1938, pl. 21, fig. 6; Barron 1975a, pl. 7, figs. 17, 18 (pl. 2, fig. 8). Remarks: This species occurs in post-Monterey rocks in California, including the Sisquoc Formation (Barron 1975a; this paper), the Etchegoin and San Joaquin Formations (Lohman 1938), and the Purisima Formation (Barron unpublished data).

Coscinodiscus sp. cf. C. vetustissimus Pantocsek. Remarks: Specimens observed are similar to $C$. vetustissimus Pantocsek of Lohman 1938, pl. 20, fig. 7 (pl. 2, fig. 6).

Cymbella sp. cf. C. prostrata (Berkeley) Grun

Delphineis sachalinensis (Sheshukova-Poretzkaya) Barron et Baldauf, n. comb. Basionym: Rhaphoneis sachalinensis SheshukovaPoretzkaya, 1967, pl. 42, fig. 2. Illustrations: Schrader, 1973, pl. 23, fig. 20 , pl. 25 , figs. 5, 7, 8, 14-16; Barron 1975a, pl. 12, fig. 3 . Remarks: Specimens possess typical Delphineis apices, which are penetrated by two fine pores.

Delphineis simbirskiana (Grunow) Barron et Baldauf, n. comb. Basionym: Rhaphoneis simbirskiana Grunow in Pantocsek 1886, p. 36, pl. 18, fig. 162. Illustrations: Barron 1975a, pl. 12, fig. 4 (pl. 3, fig. 6). Remarks: Specimens possess the typical Delphineis apices, which are penetrated by two fine pores.

\section{Denticulopsis hustedtii (Simonsen et Kanaya) Simonsen}

Denticulopsis kamtschatica (Zabelina) Simonsen (pl. 2, fig. 4). Remarks: The true forms with no more than six pseudoseptae in 10 $\mu \mathrm{m}$ do not range below the Pliocene in California (Harper 1977; Barron 1976a). This species is observed in the Sisquoc Formation (Simonsen and Kanaya 1961; this paper), the Capistrano Formation (Barron 1976a), and the Purisima Formation (Addicott et al. 1978).

Denticulopsis lauta (Bailey) Simonsen Grammatophora angulosa Ehrenberg

Hemidiscus cuneiformis Wallich. Remarks: H. simplicissimus Hanna et Grant is tabulated in this manuscript with $H$. cuneiformis. 
Hemidiscus ovalis Lohman 1938, pl. 22, fig. 9; Andrews 1980, pl. 2, fig. 10; pl. 5, fig. 9 (pl. 2, fig. 3). Synonym: Hemidiscus weissflogi sensu Koizumi 1972, pl. 43, fig. 14. Remarks: H. ovalis was described from the San Joaquin Formation and has not been observed in the Monterey Formation. Andrews (1980) figured it from lower Pliocene strata exposed in Petersburg, Virginia, and suggests that it is a brackish water form.

\section{Hyalodiscus dentatus Korotkevicz}

Lithodesmium cornigerum Brun (pl. 3, figs. 1, 3, 5). Remarks: Two forms are observed in the Harris Grade flora, a form with long extended apices as recorded by Hanna 1930, pl. 14, figs. 9, 10 and Wornardt 1967, fig. 131 (pl. 3, figs. 3, 5) and a form with shorter apices, which is equivalent to L. cornigerum of Barron 1976a, pl. 1, fig. 14 (pl. 3, fig. 1). Both forms are included together in this manuscript, because they are found together in the same populations and appear to have the same stratigraphic range. Lithodesmium cornigerum is not present in the Monterey Formation; however, it occurs in the Siquoc Formation, the lower Capistrano Formation (Barron 1976a), the Etchegoin Formation (Lohman 1938), and the Purisima Formation (Barron unpublished data).

Lithodesmium minusculum Grunow in Van Heurck

Navicula hennedyi Wm. Smith

Navicula lyra Ehrenberg

Navicula optima Hanna

Nitzschia fossilis (Frenguelli) Kanaya et Koizumi

Nitzschia granulata Grunow; Lohman 1938, pl. 22, fig. 10; Barron 1976a, pl. 3, fig. 2. Remarks: This post-Monterey diatom has been observed in the Capistrano Formation (Barron 1976a), the Etchegoin, San Joaquin, and Tulare Formations (Lohman 1938), and the Capistrano Formation (Barron unpublished data).

\section{Nitzschia reinholdii Kanaya ex Barron et Baldauf (pl. 2, fig. 7)}

Validation: Kanaya first proposed Nitzschia reinholdii in Kanaya and Koizumi (1970), but he failed to designate a type specimen and gave a very brief description in Japanese. More complete descriptions were given by Koizumi (1972, p. 351) and Schrader (1973, p. 708 ), but both these workers continued to refer the species to Kanaya and failed to designate a type. Simonsen $(1974$, p. 54) recognized that Kanaya could not be considered the author, and he considered Schrader (1973) as the author of the species. Unfortunately, neither Schrader (1973) nor other workers discussing N. reinholdii (e.g. Ko- izumi 1972; Simonsen 1974; Akiba and Yanagasawa 1986) have designated a type specimen, and $N$. reinholdii remains invalid according to Article 37 of the International Code of Botanical Nomenclature (Sancetta et al. 1985).

Wornardt (1967) provided some of the earliest good illustrations of $N$. reinholdii, but he referred to the specimens as $N$. pliocena (Brun) Wornardt. Nevertheless, Wornardt's (1967) illustrations have been referred to $N$. reinholdii Kanaya by Koizumi (1972), Schrader(1973), and most other modern workers. Both of Wornardt's (1967) illustrated specimens are labeled with hypotype numbers and are stored at the California Academy of Sciences, San Francisco. Therefore, it is proposed that figure 212 of Wornardt (1967) (CAS no. 3858) from locality 27295-29 (CAS), Harris Grade, Santa Barbara County, California, be the holotype for $N$. reinholdii Kanaya, emend. Koizumi (1972), Schrader (1973), ex Barron et Baldauf. Figure 213 of Wornardt (1967) (CAS no. 3859) from the same locality as the holotype is proposed as an isotype.

Description: From Schrader (1973, p. 708) - "Valves elliptical with slightly convex margins, 42-65 $\mu \mathrm{m}$ long, 9-12 $\mu \mathrm{m}$ wide. Apices slightly acute, broadly rounded. Transapical costae 10-12 in $10 \mu \mathrm{m}$, between the costae (intercostal membranes) two transapical rows, near the costae, about 20 in $10 \mu \mathrm{m}$. Rows punctate, about 22 in 10 $\mu \mathrm{m}$. Punctae in decussate arrangement forming oblique rows. Transapical costae and rows slightly rounded near the apices. Two apical lines near the raphe-lacking margin at the interior side of the valves forming the inner openings of the inner pores. Inner pores small elliptical. Raphe marginal, keel strong. About 13 keel punctae in 10 $\mu \mathrm{m}$."

Remarks: The similarity of $N$. reinholdii to $N$. marina Grunow is discussed by Kanaya and Koizumi (1970), Koizumi (1972), Schrader (1973), Baldauf (1984), and Akiba and Yanagasawa (1986). Basically, $N$. reinholdii has margins that are somewhat more convex than those of $N$. marina, and the raphe of $N$. reinholdii is not inturned at the apices as it is in N. marina. Baldauf (1984) illustrated forms that are intermediate between the two species.

\section{Nitzschia rolandii Schrader}

Odontella aurita (Lyngbye) Agardh. Synonym: Biddulphia aurita (Lyngbye) Brébisson.

Paralia sulcata (Ehrenberg) Cleve. Synonym: Melosira sulcata (Ehrenberg) Kützing.

\section{PLATE 1}

1 Thalassiosira praeoestrupii Dumont, Baldauf and Barron Sample H-7, diameter $33 \mu \mathrm{m}$.

2 Thalassiosira sp. aff. T. plicata Schrader Sample H-1, diameter $48 \mu \mathrm{m}$.

3 Thalassiosira oestrupii (Ostenfeld) Proshkina-Lavrenko Sample H-11, diameter $19 \mu \mathrm{m}$.

4 Thalassiosira hyalinopsis Barron Approaching T. nativa sensu Schrader (1973) in morphology. Sample H-2A, diameter $23 \mu \mathrm{m}$.

5 Thalassiosira hyalinopsis Barron Sample H-2A, diameter $25 \mu \mathrm{m}$.
6 Thalassiosira nativa Sheshukova-Poretzkaya sensu Schrader Sample H-4A, diameter $19 \mu \mathrm{m}$.

7 Thalassiosira antiqua (Grunow) Cleve-Euler Scanning electron microscope photograph. Sample H-3C. Scale bar $=10 \mu \mathrm{m}$.

8 Thalassiosira sp. aff. T. kryophila (Grunow) Jørgensen Sample H-11, diameter $48 \mu \mathrm{m}$.

9 Thalassiosira hyalinopsis Barron Scanning electron microscope photograph. Sample H-3C. Scale bar $=10 \mu \mathrm{m}$. 

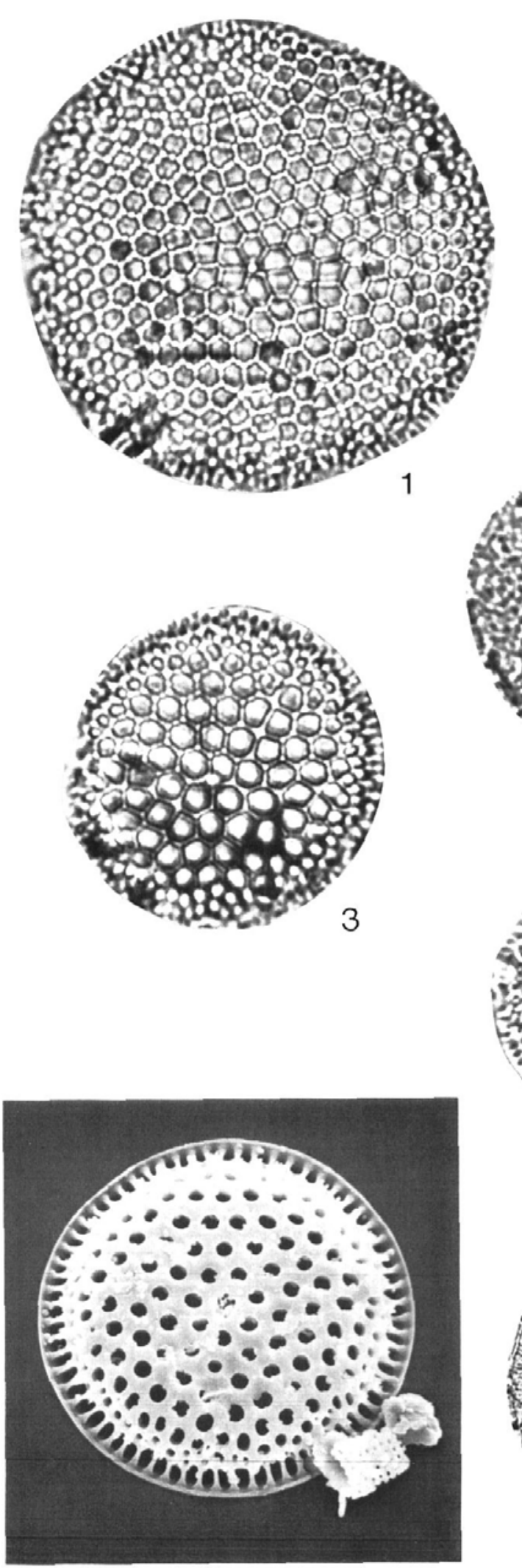
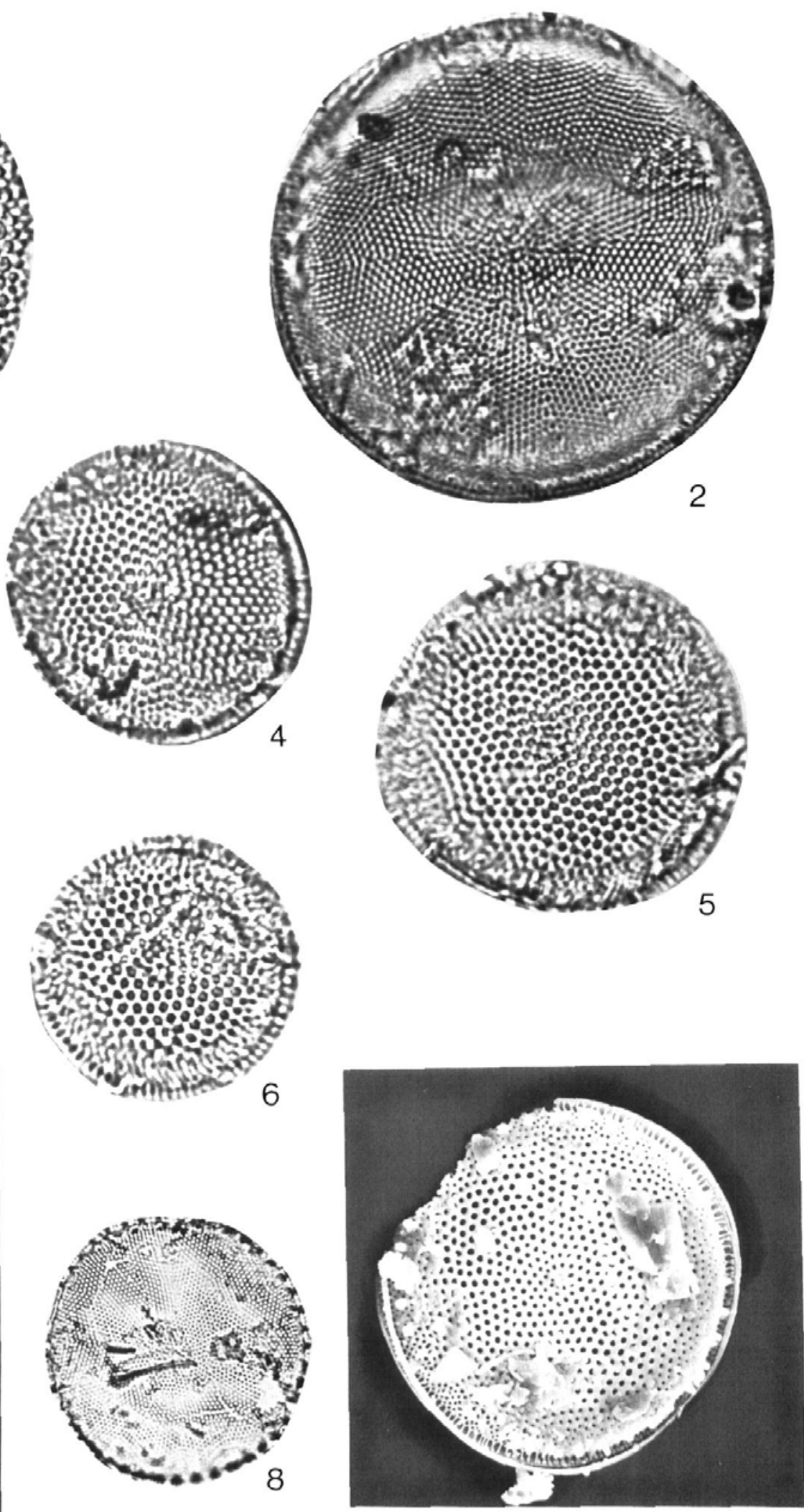
Paralia sulcata var. biseriata (Grunow) Cleve Paralia sulcata var. coronata (Ehrenberg) Cleve Rhaphoneis amphiceros Ehrenberg

Rhaphoneis amphiceros var. elongata Peragallo Rhaphoneis angularis Lohman 1938, pl. 22, figs. 6-8

Rhaphoneis fatula Lohman 1938, pl. 22, fig. 5 (pl. 3, fig. 8). Remarks: This post-Monterey diatom is present in the Sisquoc Formation (this paper), the San Joaquin Formation (Lohman 1938), and the Purisima Formation (Barron unpublished data).

Rhaphoneis gemmifera Ehrenberg; Andrews 1975, pl. 2, figs. 28, 29; pl. 4, figs. 56-60; pl. 5, figs. 69,70 .

\section{Rhizosolenia barboi Brun \\ Rhizosolenia hebetata f. hiemalisGran \\ Rhizosolenia styliformis Brightwell}

Rossiella sp. cf. R. tatsunokuchiensis (Koizumi) Gersonde. Synonym: Rhaphoneis tatsunokuchiensis Koizumi 1972, pl. 42, figs. 3, 4; Cussia tatsunokuchiensis (Koizumi) Schrader; Koizumi, 1975, pl. 4, figs. 33-35. Remarks: $R$. tatsunokuchiensis is not present in the Monterey Formation, but it has been observed in the Sisquoc Formation (this paper) and the Etchegoin Formation (Barron unpublished data).

\section{Stephanogonia polyacantha Forti}

Stephanopyxis turris (Greville et Arnott) Ralfs

Thalassionema nitzschioides Grunow in Van Heurck

Thalassionema nitzschioides var. parva Heiden et Kolbe

Thalassiosira antiqua (Grunow) Cleve-Euler (pl. 1, fig. 7)

Thalassiosira eccentrica (Ehrenberg) Cleve

Thalassiosira eccentrica (Ehrenberg) Cleve, fine form (pl. 3, fig. 7). Remarks: Tabulated here are forms with small areolae (9-10 in 10 $\mu \mathrm{m})$ and a center which is slightly indented.

Thalassiosira hyalinopsis Barron 1975a, pl. 13, figs. 12, 15 (pl. 1, figs. 4, 5, 9). Remarks: This species intergrades with $T$. nativa Sheshukova-Poretzkaya sensu Schrader 1973. Thalassiosira hyalinopsis occurs in the Sisquoc Formation (this paper), and it is sparse and sporadic in the Capistrano Formation (Barron 1976a), the Etchegoin Formation (Barron unpublished data), and the Purisima Formation (Barron unpublished data).

Thalassiosira jacksonii Koizumi et Barron in Koizumi 1980, pl. 1, figs. 11-14 (pl. 2, fig. 5). Remarks: This species does not occur in the Monterey Formation.

Thalassiosira sp. aff. T. kryophila (Grunow) Jørgensen; Koizumi 1972, pl. 43, fig. 9; Barron 1975a, pl. 14, fig. 1 (pl. 1, fig. 8). Synonym:
Thalassiosira plicata sensu Whiting and Schrader 1985, pl. 2, figs. 20, 21. Remarks: This species is not present in the Monterey Formation.

Thalassiosira leptopus (Grunow) Hasle et Fryxell (pl. 3, figs. 2, 4?). Synonym: Thalassiosira lineata Jousé sensu Barron 1975a, pl. 14, fig. 2.

Thalassiosira multipora Whiting et Schrader 1985, p. 258, pl. 2, figs. 11, 16, 17 (pl. 2, fig. 1). Remarks: This species has also been observed in the Purisima Formation (Barron unpublished data), but it does not occur in the Monterey Formation.

Thalassiosira nativa Sheshukova-Poretzkaya sensu Schrader 1973, pl. 11, figs. 23, 24. Barron 1975a, pl. 14, figs, 4-6 (pl, 1, fig. 6).

Thalassiosira oestrupii (Ostenfeld) Proshkina-Lavrenko; Schrader 1973, pl. 11, figs. 16-22, 26-33, 36, 39-45; not Barron 1976a, pl. 2, fig. 19 (pl. 1, fig. 3). Remarks: This Pliocene to Holocene diatom is present in the Sisquoc Formation (this paper), the Capistrano Formation (Barron and Keller 1983), the Malaga Mudstone Member (Rowell 1981); and the Purisima Formation (Barron unpublished data).

Thalassiosira sp. aff. T. plicata Schrader 1974, pl. 3, figs. 4-6, 7-9 (pl. 1, fig. 2).

Thalassiosira praeoestrupii Dumont, Baldauf and Barron (pl. 1, fig. 1). Synonym: Thalassiosira oestrupii sensu Barron 1976a, pl. 2, fig. 19. Remarks: In this species, the central accessory pore (strutted process) is separated from the submarginal pore (process) by at least four areolae (Dumont et al. 1986). In $T$. oestrupii, the separation of the two pores is $2-3$ areolae.

Thalassiosira symbolophora Schrader 1974, pl. 4, figs. 1-8 (pl. 2, fig. 2). Remarks: This diatom has not been observed in the Monterey Formation.

Thalassiosira sp. cf. T. zabelinae Jousé; Shrader 1973, pl. 14, figs. 1, 2. Remarks: This typically cold-water species has not been observed in the Monterey Formation.

Thalassiothrix longissima Cleve et Grunow; Schrader 1973, pl. 23, figs. $7,17,18$.

\section{ACKNOWLEDGMENTS}

We thank Michael Dumont of Chevron, U.S.A., Peter Ramirez of the U.S. Geological Survey, and Robert Arends of UNOCAL for helpful discussions during this study. We also thank Sean M. Stone of the U.S. Geological Survey and Michael Dumont for assistance in the field. This manuscript

\section{PLATE 2}

1 Thalassiosira multipora Whiting et Schrader Sample H-11, diameter $48 \mu \mathrm{m}$.

2 Thalassiosira symbolophora Schrader Sample H-11, diameter $32 \mu \mathrm{m}$. Low and high focus.

3 Hemidiscus ovalis Lohman Sample H-8, length $22 \mu \mathrm{m}$.

4 Denticulopsis kamtschatica (Zabelina) Simonsen Sample H-11, length $13 \mu \mathrm{m}$.
5 Thalassiosira jacksonii Koizumi et Barron Sample H-9, diameter $28 \mu \mathrm{m}$.

6 Coscinodiscus sp. cf. C. vetustissimus Pantocsek Sample H-8, diameter $51 \mu \mathrm{m}$.

7 Nitzschia reinholdii Kanaya ex Barron et Baldauf Sample H-3A, length $52 \mu \mathrm{m}$.

8 Coscinodiscus subtilis Ehrenberg Sample H-8, diameter $63 \mu \mathrm{m}$. 

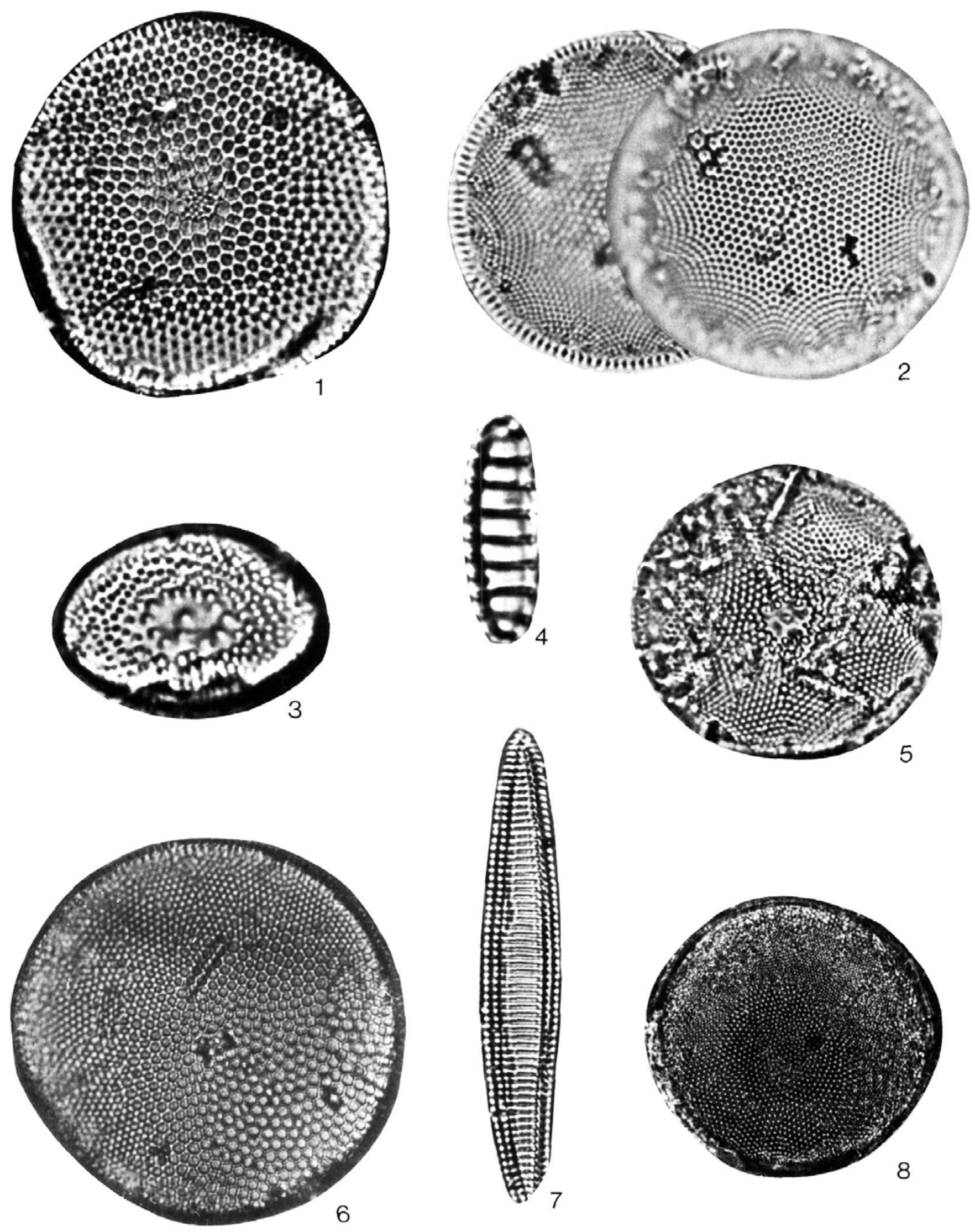
was reviewed by David Bukry of the Minerals Management Service, Robert Arends, Itaru Koizumi of Osaka University, and an anonymous reviewer. This is Ocean Drilling Program contribution no. ODP-P85-000.

\section{REFERENCES}

ADDICOTT, W. O., BARRON, J. A., and MILLER, J. W., 1978. Marine late Neogene sequence near Santa Cruz, California. U.S. Geological Survey, Open-File Report, 78-466:97-109.

AKIBA, F., 1982. Taxonomy and biostratigraphic significance of a new diatom, Thalassionema schraderi. Bacillaria, 5:43-61.

AKIBA, F., and YANAGASAWA, Y., 1986. Taxonomy, morphology and phylogeny of the Neogene diatom zonal marker species in the middle-to-high latitudes of the North Pacific. In: Kagami, H., Karig, D. E., Coulbourn, W. T., et al., Initial Reports of the Deep Sea Drilling Project, Volume 87:483-554. Washington, D.C.: U.S. Government Printing Office.

ANDREWS, G. W., 1975. Taxonomy and stratigraphic occurrence of the marine diatom genus Rhaphoneis. Nova Hedwigia, Beihefte, 53:193-222, pls. $1-5$.

1980. Neogene diatoms from Petersburg, Virginia. Micropaleontology, 26(1):17-48, pls. 1-6.

BALDAUF, J. G., 1984. Cenozoic diatom biostratigraphy and paleoceanography of the Rockall Plateau region, North Atlantic, Deep Sea Drilling Project Leg 81. In: Roberts, D. G., Schnitker, D., et al., Initial Reports of the Deep Sea Drilling Project, Volume 81:439-478. Washington, D.C.: U.S. Government Printing Office.

BALDAUF, J. G., and BARRON, J. A., 1982. Diatom biostratigraphy and paleoecology of the type section of the Luisian Stage, central California. Micropaleontology, 28(1):59-84.

BARRON, J. A., 1974. The late Miocene-early Pliocene marine diatom assemblage of southern California. Ph.D. dissertation, University of California, Los Angeles, $289 \mathrm{pp}$.

1975a. Late Miocene-early Pliocene marine diatoms from southern California. Palaeontographica, 151(B):97-170, pls. 1-15.

1975b. Marine diatom biostratigraphy of the upper Miocene-lower Pliocene strata of southern California. Journal of $\mathrm{Pa}-$ leontology, 49:619-632.

1976a. Revised Miocene and Pliocene diatom biostratig- raphy of Upper Newport Bay, Newport Beach, California. Marine Micropaleontology, 1:27-63.

, 1976b. Middle Miocene-lower Pliocene marine diatom and silicoflagellate correlations in the California area. In: Fritsche, A. E., et al., Eds., The Neogene Symposium, Pacific Section, Society of Economic Paleontologists and Mineralogists Meeting, San Francisco, California, 117-124.

_ $1976 \mathrm{c}$. Marine diatom and silicoflagellate biostratigraphy of the type Delmontian Stage and the type Bolivina obliqua Zone, California. Journal of Research, U.S. Geological Survey, 4(3):339351 .

, 1980. Lower Miocene to Quaternary diatom biostratigraphy of Leg 57, off northeastern Japan, Deep Sea Drilling Project. In: Scientific Party, Initial Reports of the Deep Sea Drilling Project, Volumes 56, 57:641-685. Washington, D.C.: U.S. Government Printing Office.

_ 1981. Late Cenozoic diatom biostratigraphy and paleoceanography of the middle-latitude eastern North Pacific, Deep Sea Drilling Project Leg 63. In: Yeats, R., Haq, B. U., et al., Initial Reports of the Deep Sea Drilling Project, Volume 63: 507-538. Washington, D.C.: U.S. Government Printing Office.

_ 1985. Miocene to Holocene planktic diatoms. In: Bolli, H. M., Saunders, J. B., and Perch-Nielsen, K., Plankton stratigraphy, 763-805. Cambridge: Cambridge University Press.

1986. Paleoceanographic and tectonic controls on deposition of the Monterey Formation and related siliceous rocks in California. Palaeogeography, Palaeoclimatology, Palaeoecology, 53: 27-45.

BARRON, J. A., and KELLER, G., 1983. Paleotemperature oscillations in the middle and late Miocene of the northeastern Pacific. Micropaleontology, 29(2):150-181, pls. 1-3.

BARRON, J. A., KELLER, G., and DUNN, D. A., 1985. A multiple microfossil biochronology for the Miocene. In: Kennett, J. P., Ed., The Miocene Ocean: paleoceanography and biogeography. Geological Society of America Memoir, 163:21-36.

BERGGREN, W. A., KENT, D. V., FLYNN, J. J., and VAN COUVERING, J. A., 1985. Cenozoic geochronology. Geological Society of America, Bulletin, 96:1407-1418.

BURCKLE, L. H., 1978. Early Miocene to Pliocene diatom datum levels for the equatorial Pacific. In: Proceedings, Second Working Group Meeting, Biostratigraphic Datum-Planes of the Pacific

\section{PLATE 3}

1 Lithodesmium cornigerum Brun

Form with short apices. Scanning electron microscope photograph. Sample H-3C. Scale bar $=10 \mu \mathrm{m}$.

2 Thalassiosira leptopus (Grunow) Hasle et Fryxell Scanning electron microscope photograph. Sample H-3C, scale bar $=10 \mu \mathrm{m}$.

3 Lithodesmium cornigerum Brun

Form with long apices. Sample H-3A. Base $48 \mu \mathrm{m}$.

4 Thalassiosira sp. cf. T. leptopus (Grunow) Hasle et Fryxell Sample H-11, diameter $28 \mu \mathrm{m}$.
5 Lithodesmium cornigerum Brun

Form with long apices. Sample H-8, base $49 \mu$ m.

6 Delphineis simbirskiana (Grunow) Barron et Baldauf Sample H-4A, length $25 \mu \mathrm{m}$.

7 Thalassiosira eccentrica (Ehrenberg) Cleve Fine form. Sample H-11, diameter $26 \mu \mathrm{m}$.

8 Rhaphoneis fatula Lohman Sample H-8, length $42 \mu \mathrm{m}$. 

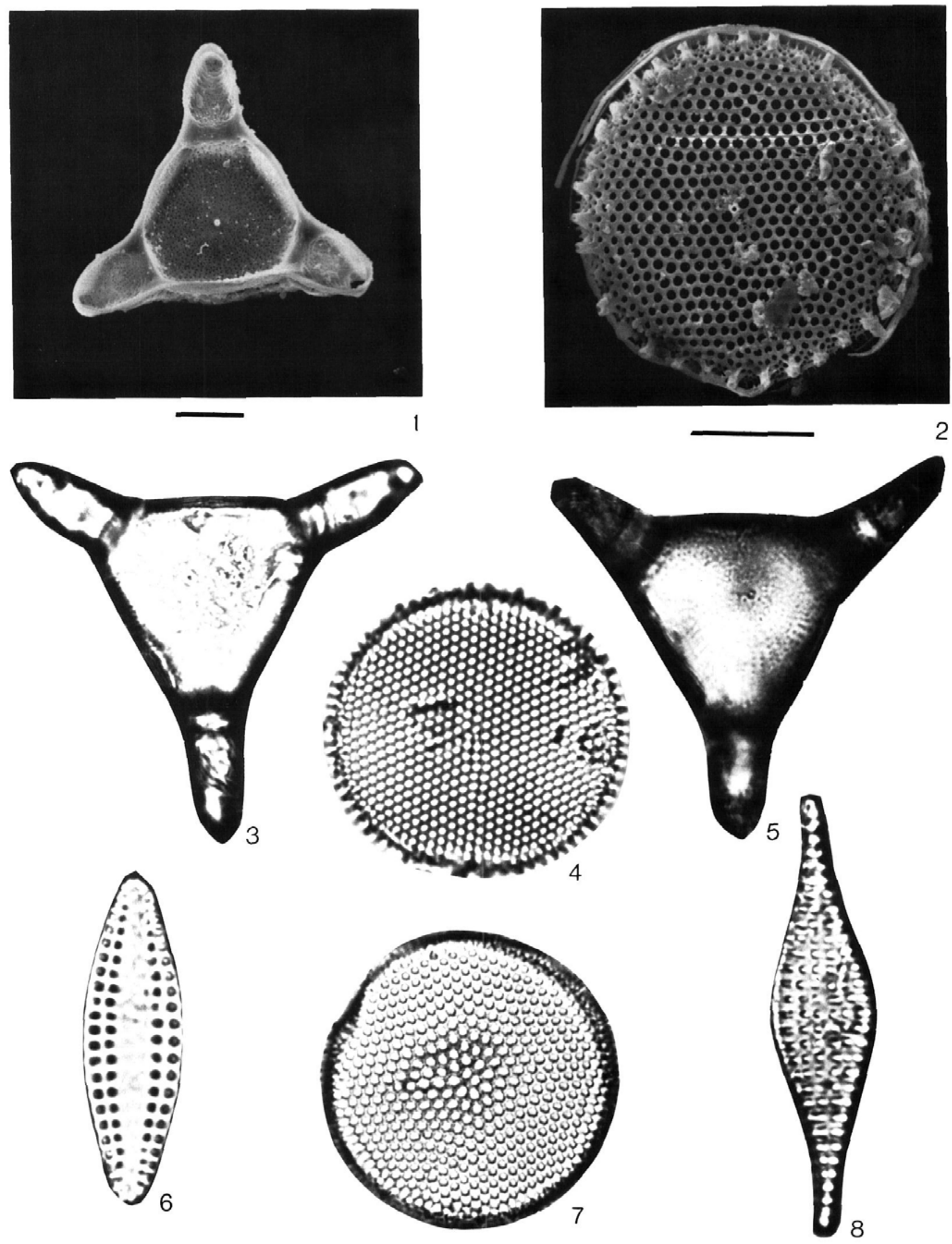
Neogene, IGCP Project 114. Republic of Indonesia Ministry of Mines and Energy, Geological Research and Development Centre, Special Publication, 1:25-44.

BURCKLE, L. H., and OPDYKE, N. D., 1977. Late Neogene diatom correlations in the circum-Pacific. Proceedings of the First International Congress on Pacific Neogene Stratigraphy, Tokyo, Kaiyo Shuppan, 1976:255-284.

- 1985. Latest Miocene/earliest Pliocene diatom correlations in the North Pacific. In: Kennett, J. P., Ed., The Miocene Ocean: paleoceanography and biogeography. Geological Society of America Memoir, 163:37-48.

DIBBLEE, T. W., JR., 1950. Geology of southwestern Santa Barbara County, California. California Division of Mines, Bulletin, 150: $1-84$, maps.

—_ 1966. Geology of the central Santa Ynez Mountains, Santa Barbara County, California. California Division of Mines \& Geology, Bulletin, 186:1-99, maps.

DUMONT, M. P., 1984. Miocene/Pliocene Epoch boundary from diatom biostratigraphy in the Lompoc, California region. Abstracts with Programs 1984, 97th Annual Meeting, Geological Society of America, Reno, Nevada, 16(6):496.

DUMONT, M. P., BALDAUF, J. G., and BARRON, J. A., 1986. Thalassiosira praeoestrupii: a new diatom species for recognizing the Miocene/Pliocene boundary in coastal California. Micropaleontology, 32(4):382-387 (present volume).

HANNA, G. D., 1930. Observations on Lithodesmium cornigerum Brun. Journal of Paleontology, 4(2):189-191, pl. 14.

HARPER, H. E., JR., 1977. Diatom biostratigraphy of the MiocenePliocene boundary in marine strata of the circum-North Pacific. Ph.D. dissertation, Harvard University, $112 \mathrm{pp}$.

INGLE, J. C., JR., 1981. Origin of Neogene diatomites around the North Pacific rim. In: Garrison, R. E., et al., Eds., The Monterey Formation and related siliceous rocks of California. Society of Economic Paleontologists and Mineralogists, Pacific Section, Special Publication: 159-179.

ISAACS, C. M., 1981. Lithostratigraphy of the Monterey Formation, Goleta to Point Conception, Santa Barbara coast, California. In: Isaacs, C. M., Ed., Guide to the Monterey Formation in the California coastal area, Ventura to San Luis Obispo. American Association of Petroleum Geologists, Pacific Section, Special Publication, 52:9-23.

KANAYA, T., and KOIZUMI, I., 1970. The progress in the younger Cenozoic diatom biostratigraphy in the circum-Pacific region. Journal of Marine Geology of Japan, 6(2):47-66 (in Japanese with English abstract).

KELLER, G., 1979. Early Pliocene to Pleistocene planktonic foraminiferal datum levels in the North Pacific: DSDP Sites 173, 310, 296. Marine Micropaleontology, 4: 281-294.

KLEINPELL, R. M., 1980. The Miocene stratigraphy of California revisited. American Association of Petroleum Geologists, Tulsa, $349 \mathrm{pp}$.

KOIZUMI, I., 1972. Marine diatom flora of the Pliocene Tatsunokuchi Formation in Fukushima Prefecture. Paleontological Society of Japan, Transaction Proceedings, n. ser., 86:340-359, pls. $42,43$.

1973. The late Cenozoic diatoms of Sites 183-193, Leg 19, Deep Sea Drilling Project. In: Creager, J. S., Scholl, D. W., et al., Initial Reports of the Deep Sea Drilling Project, 19:805-855. Washington, D.C.: U.S. Government Printing Office.
1975. Neogene diatoms from the northwestern Pacific Ocean, Deep Sea Drilling Project. In: Larson, R. L., Moberly, R., et al., Initial Reports of the the Deep Sea Drilling Project, Volume 32: 865-889. Washington, D.C.: U.S. Government Printing Office.

1980. Neogene diatoms from the Emperor Seamount Chain, Leg 55, Deep Sea Drilling Project. In: Jackson, E. D., Koizumi, I., et al., Initial Reports of the Deep Sea Drilling Project, Volume 55:387-400. Washington, D.C.: U.S. Government Printing Office.

_ 1985. Diatom biochronology for late Cenozoic northwest Pacific. Journal of the Geological Society of Japan, 91(3):195-211.

KOIZUMI, I., and TANIMURA, Y., 1985. Neogene diatom biostratigraphy of the middle latitude western North Pacific, Deep Sea Drilling Project Leg 86. In: Heath, G. R., Burckle, L. H., et al., Initial Reports of the Deep Sea Drilling Project, 86:269-300. Washington, D.C.: U.S. Government Printing Office.

LOHMAN, K. E., 1938. Pliocene diatoms from the Kettleman Hills, California. U.S. Geological Survey Professional Paper 189-C:8194, pls. 20-23.

MADRID, V. M., STUART, R. M., and VEROSUB, K. L., In press. Magnetostratigraphy of the late Neogene Purisima Formation, Santa Cruz County, California. Earth and Planetary Science Letters.

MARUYAMA, T., 1984. Miocene diatom biostratigraphy of onshore sequences on the Pacific side of northeast Japan with reference to DSDP Hole 438A (Part 2). Science Reports, Tohoku University, Sendai, Second Series, 55(1):77-140, pls. 11-15.

PANTOCSEK, J., 1886. Beiträge zur Kenntniss der fossilen Bacillarien Ungarns. Teil I. Marine Bacillarien, 74 pp., 30 pls.

PORTER, W. W., JR., 1932. Lower Pliocene in Santa Maria district, California. American Association of Petroleum Geologists Bulletin, 16:139-140.

ROWELL, H. C., 1981. Diatom biostratigraphy of the Monterey Formation, Palos Verdes Hills, California. In: Garrison, R. E., et al., Eds., The Monterey Formation and related siliceous rocks of California. Pacific Section, Society of Economic Paleontologists and Mineralogists, Los Angeles, 55-70.

SANCETTA, C. A., CARROLL, S. E., HILLMAN, N. S., JANAL, M. J., and VAN COUVERING, J. A., Eds., Catalogue of diatoms, Book 2, 1985. New York: Micropaleontology Press.

SCHMIDT, A., ET AL., 1874-1959. Atlas der Diatomaceenkunde, pls. 1-480. Leipzig: O. R. Reisland.

SCHRADER, H. J., 1973. Cenozoic diatoms from the northeast Pacific, Leg 18. In: Kulm, L. D., von Huene, R., et al., Initial Reports of the Deep Sea Drilling Project, Volume 18: 673-797. Washington, D.C.: U.S. Government Printing Office.

__, 1974 . Cenozoic marine planktonic diatom stratigraphy of the tropical Indian Ocean. In: Fisher, R. L., Bunce, C. L., et al., Initial Reports of the Deep Sea Drilling Project, Volume 24:887967. Washington, D.C.: U.S. Government Printing Office.

SCHRADER, H. J., and GERSONDE, R., 1978. Diatoms and silicoflagellates. Utrecht Micropaleontological Bulletins, 17:129-176.

SHESHUKOVA-PORETZKAYA, V. S., 1967. Neogenovye morskie diatomovye vodorosli Sakhalina i Kamchatki. Leningradskii Orden Lenina Gosudarstvennyi Universitet imeni A. Zhdanova, Izdatel'stvo Leningradskogo Universiteta: 1-432, pls. 1-50.

SIMONSEN, R., 1974. The diatom plankton of the Indian Ocean Expedition of R/V Meteor 1964-1965. "Meteor" Forschungsergebnisse, Herausgegeben von der Deutschen Forschungsgemein- 
schaft, Reihe D, No. 19, 66 pp., 41 pls. Berlin: Gebrüder Borntraeger.

SIMONSEN, R., and KANAYA, T., 1961. Notes on the marine species of the diatom genus Denticula Kützing. Internationale Revue der Gesamten Hydrobiologie, 46:498-513.

STANLEY, K. O., and SURDHAM, R. C., 1984. The role of wrench fault tectonics and relative changes of sea level on deposition of upper Miocene-Pliocene Pismo Formation, Pismo Syncline, California. In: SEPM Guidebook No. 2, Stratigraphic, tectonic, thermal, and diagenetic histories of the Monterey Formation, Pismo and Huasna Basin, California, Mid-year Meeting. Society of Economic Palentologists and Minerologists, Aug. 13-16, 1984, San Jose, California, 21-34.

VAIL, P. R., and HARDENBOL, J., 1979. Sea-level changes during the Tertiary. Oceanus, 22:71-79.

WHITING, M. C., and SCHRADER, H. J., 1985. Late Miocene to Early Pliocene diatom and silicoflagellate floras from the Oregon coast and continental shelf. Micropaleontology, 31(3):249-270, pls. 1-8.
WOODRING, W. P., and BRAMLETTE, M. N., 1950. Geology and paleontology of the Santa Maria district, California. U.S. Geological Survey, Professional Paper 222:1-142, maps.

WOODRING, W. P., BRAMLETTE, M. N., and LOHMAN, K. E., 1943. Stratigraphy and paleontology of Santa Maria district, California. American Association of Petroleum Geologists Bulletin, 27(10):1335-1360.

WORNARDT, W. W., JR., 1963. Stratigraphic distribution of diatom floras from the "Mio-Pliocene" of California. Ph.D. dissertation, University of California, Berkeley, $208 \mathrm{pp}$.

1967. Miocene and Pliocene marine diatoms from California. California Academy of Science, Occasional Papers, 63:1-108, 217 figs.

Manuscript received December 30, 1985.

Revised manuscript accepted May 8, 1986. 